\title{
Validation of the definitions of nursing diagnoses for individuals with Aids
}

\author{
Validação das definições de diagnósticos de enfermagem para pessoas com Aids \\ Validación de las definiciones de los diagnósticos enfermeros para personas con Sida
}

Vinicius Lino de Souza Neto'

ORCID: 0000-0001-8269-2634

Rayanne Teresa da Silva Costa'

ORCID: 0000-0002-5619-2166

Wenysson Noleto dos Santos'

ORCID: 0000-0002-2093-5415

Sâmara Fontes Fernandes" ORCID: 0000-0002-2105-0248

Dhyanine Morais de Lima' ORCID: 0000-0002-9723-705X

Richardson Augusto Rosendo da Silva' ORCID: 0000-0001-6290-9365

'Universidade Federal do Rio Grande do Norte. Natal, Rio Grande do Norte, Brazil. "Universidade do Estado do Rio Grande do Norte. Mossoró, Rio Grande do Norte, Brazil.

How to cite this article:

Souza Neto VL, Costa RTS, Santos WN, Fernandes SF, Lima DM, Silva RAR. Validation of the definitions of nursing diagnoses for individuals with Aids.

Rev Bras Enferm. 2020;73(4):e20180915.

doi: http://dx.doi.org/10.1590/0034-7167-2018-0915

Corresponding author:

Richardson Augusto Rosendo da Silva

E-mail: rirosendo@hotmail.com

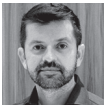

EDITOR IN CHIEF: Antonio José de Almeida Filho ASSOCIATE EDITOR: Marcos Brandão

Submission: $01-27-2019$

Approval: 07-07-2019

\section{ABSTRACT}

Objectives: to develop and validate conceptual and operational definitions of nursing diagnoses of the International Classification for Nursing Practice for people living with Aids. Methods: methodological study with 100 individuals with Aids, in a hospital school. In addition, 19 nurses selected from the Lattes platform acted as experts in the validation process. The research was conducted, using three moments: identification and validation of the nursing diagnoses; construction of the conceptual and operational definitions of the diagnoses, and content validation, using the content validity index. Results: a total of 35 diagnoses were identified and 18 had their conceptual and operational definitions validated, with validity index of $\geq 0.8$. Conclusions: the construction of the conceptual and operational definitions enables nurses to analyze the clinical inferences and endorse the nursing diagnosis, contributing to its predictive capacity.

Descriptors: Nursing; Nursing Diagnosis; Standardized Nursing Terminology; Validation Studies; Acquired Immunodeficiency Syndrome.

\section{RESUMO}

Objetivos: elaborar e validar o conteúdo das definições conceituais e operacionais dos Diagnósticos de Enfermagem da Classificação Internacional para a Prática de Enfermagem para pessoas com Aids. Métodos: estudo metodológico com cem pessoas vivendo com Aids, em um Hospital Escola. Além disso, 19 enfermeiros selecionados por meio da plataforma Lattes atuaram como juízes no processo de validação. A pesquisa foi realizada apreciando-se três momentos: identificação e validação dos diagnósticos de enfermagem; construção das definições conceituais e operacionais dos diagnósticos, e validação de conteúdo, utilizando-se o índice de validade de conteúdo. Resultados: foram identificados 35 diagnósticos, sendo validados 18 , para os quais foram construídas e validadas as definições conceituais e operacionais com índice de validade de conteúdo $\geq 0,8$. Conclusões: a construção das definições conceituais e operacionais permite que o enfermeiro possa analisar as inferências clínicas e assim reafirmar o diagnóstico de enfermagem, contribuindo para a sua capacidade preditora.

Descritores: Enfermagem; Diagnóstico de Enfermagem; Terminologia Padronizada em Enfermagem; Estudos de Validação; Síndrome de Imunodeficiência Adquirida.

\section{RESUMEN}

Objetivos: elaborar y validar el contenido de las definiciones conceptuales y operativas de los Diagnósticos Enfermeros de la Clasificación Internacional para la Práctica de Enfermería para personas que viven con el Sida. Métodos: estudio metodológico con 100 personas viviendo con Sida, en un Hospital Escuela. Además, 19 enfermeros seleccionados por medio de la plataforma Lattes actuaron como jueces en el proceso de validación. La investigación se realizó, siguiendo tres momentos: identificación y validación de los diagnósticos enfermeros; construcción de las definiciones conceptuales y operacionales de los diagnósticos y validación de contenido, utilizando el índice de validez de contenido. Resultados: se identificaron 35 diagnósticos, validando solo 18 para los cuales fueron construidas y validadas definiciones conceptuales $y$ operacionales con índice de validez de contenido $\geq 0.8$. Conclusiones: la construcción de las definiciones conceptuales y operativas permite que el enfermero pueda analizar las inferencias clínicas y así reafirmar el diagnóstico enfermero, contribuyendo a su capacidad predictora. Descriptores: Enfermería; Diagnóstico de Enfermería; Terminología Normalizada de Enfermería; Estudios de Validación; Síndrome de Inmunodeficiencia Adquirida. 
Validation of the definitions of nursing diagnoses for individuals with Aids Souza Neto VL, Costa RTS, Santos WN, Fernandes SF, Lima DM, Silva RAR.

\section{INTRODUCTION}

The advent of antiretroviral therapy (ART) has modified the clinical course of Aids, reducing mortality from the disease, improving quality of life, and redefining the experience of living with a chronic condition. However, actual global goals for infection control require efforts in the field of care beyond drug therapy, intensifying the diagnosis, and offering permanent care ${ }^{(1)}$.

In this sense, the nurse, as a health professional, plays an important role in this context, developing technical-scientific skills that favor the organization and systematization of care. To that end, the Systematization of Nursing Assistance (SNA) and the Nursing Process (NP) are means to guide, guide and structure the qualification and individualize the care of people living with Aids ${ }^{(2)}$.

Considering the need to support the nursing process for these individuals, it is important to emphasize the importance of using nursing terminologies, as it enables the identification and documentation of care standards. The International Classification for Nursing Practice (ICNP ${ }^{\circ}$ ) consists of a standardized terminology of nursing language. Its structure of terms and definitions enable the collection, description and systematic documentation of the nursing practice elements - nursing diagnoses (ND), outcomes, and interventions ${ }^{(3)}$.

Research has been carried out in the sense of instrumentalizing the SNA and operationalizing the NP in the care of people living with Aids. This results in the elaboration of conceptual (CD) and operational (OD) definitions for nursing diagnosis statements, in order to contribute to care actions and documentation of professional practice, with a view to ensuring differentiated and quality care for this clientele ${ }^{(4)}$.

In addition, they serve to: increase the reliability and validity of data related to the ND; facilitate replication of the research; increase the researcher's ability to relate findings to previous studies; and, to indicate the criteria for evaluation of nursing interventions, as the patient's condition advances ${ }^{(5-6)}$.

The study's justification is based on the hypothesis that knowledge about the conceptual and operational definitions of nursing diagnoses contributes to avoid misunderstandings in the evaluation of patients, corroborates with clinical accuracy, and contributes to the nurse's predictive capacity, optimizing nursing care practices. Nursing for people living with Aids, it is necessary to elaborate and validate the content of the ICNP ${ }^{\circ}$ nursing diagnoses definitions for people living with Aids, thus demonstrating the relevance of the present study.

The study is about a Terminological Subset for people living with Aids that was structured in four stages: identification of terms relevant to the clientele and/or health priority; cross-mapping of terms identified with the terms of the ICNP' ${ }^{\circ}$ construction of diagnostic statements, results and nursing interventions; and structuring the ICNP' terminology subset. Thus, we propose to construct $C D$ and $O D$ of the nursing diagnoses of said subset.

Given this, the questions posed were: Is it possible to develop conceptual definitions (CD) and operational definitions (OD) for the ICNP ${ }^{\circ}$ nursing diagnoses of individuals with Aids? What CD and OD of the ICNP nursing diagnoses can be validated with regard to their content for individuals with Aids?

\section{OBJECTIVES}

To develop and validate the conceptual and operational definitions of the ICNP nursing diagnoses of individuals with Aids.

\section{METHODS}

\section{Ethical aspects}

The study was conducted according the guidelines and norms regulating the research involving human beings established in Resolution 466/2012 of the National Health Council and was approved by the Committee of Ethics in Research with human beings, under the opinion $n^{\circ} 1.177 .410$.

\section{Design, period and place of study}

This was a methodological study, with a cross-section design, distributed into three moments: identification and validation of ND for individuals with Aids, using ICNP version 2017; construction of $C D$ and OD of the ND; and content validation of these definitions.

\section{Population or sample: inclusion and exclusion criteria}

The first moment consisted of identifying individuals with Aids, which was based on the number of patients receiving care in the period from 2012 to 2016, totaling 1,468. The formula for finite populations was used to calculate the sample, considering a $95 \%$ confidence level $(Z \infty=1.96)$, a sampling error of $10 \%$, population of 1,468 , resulting in a sample of 91 individuals. The final sample was established at 100 individuals, and was selected by convenience, consecutively.

The following criteria were adopted for sample selection: clinically diagnosed with Aids; age greater than 18 years; hospitalized at the time of data collection. The exclusion criterion was: having some type of mental disorder, identified by means of Mini-Mental State Examination (MMSE) ${ }^{(7)}$. It is noteworthy that people living with Aids participated in the study, and an interview and physical examination were carried out for the subsequent identification of ND, since there was no documentation of diagnoses based on the ICNP in the medical records. In addition, five nurses in Infectology and who had been working for more than 10 years in the referred hospital, which evaluated whether the ND identified by the researchers were actually present in this clientele.

In addition, in order to promote greater diagnostic accuracy to the study, it was decided to select judges. Thus, a research was carried out by accessing the Lattes Platform, from the website of the National Council for Scientific and Technological Development (CNPq), and the following eligibility criteria were adopted: Nurses who had at least the academic degree of master, worked with process and with ICNP $^{\circ}$ and focused on infectious diseases in care, teaching and / or research. In response, invitations were sent to 31 Nurses who met the inclusion criteria, of whom 24 accepted to participate in the study in the first round of Delphi and 19 in the second.

\section{Study Protocol}

In the first moment, the ND for individuals living with Aids were identified by means of a cross-sectional study, with a quantitative 
approach, conducted at a University Hospital in the Northeast of Brazil, between February and April of 2017, in the respective service. In the second period, between May and June of 2017, the CD and OD of the ND statements were developed. In order to develop the $C D$ and $O D$ of the validated ND, the following steps were used: 1) development of a preliminary definition; 2) literature review; 3) mapping of the meaning of the concept; and 4) statement of $C D$ and OD, which represents the definition as it is constructed according to the idea initially established. Professional practice, in the context of the nurse's actions with a specific population, associated to readings on the subject obtained in the literature review, was used to develop these definitions. And finally, in the third moment, the content validation of CD and OD of the ICNP ND for individuals with Aids was performed. The CD and OD were submitted to the content validation process by a group of experts, using the Delphi technique ${ }^{(8)}$ between August and October of 2017.

In the first moment the data collection with people living with Aids occurred through an interview and physical examination. For this purpose, a structured instrument containing four domains was used: identification; interview; physical exam; nurses' impressions and intercurrences, which was structured by Wanda Horta's basic human needs theory with their respective psychobiological, social, and spiritual needs.

The ND were then identified by the researchers, a doctor and another master, using ICNP` version 2017, respecting the medical history of all people living with Aids. Thus, for the selection process of the statements of ND, Risner's model of reasoning was adopted, based on the principles of grouping of data, the comparison with standards, norms and theories, and the collection of diagnostic hypotheses ${ }^{(8)}$.

Subsequently, the ND identified by the researchers underwent a process of consensus validation through a focus group, with the participation of five Nurses specialized in Infectious Diseases, with more than 10 years of experience in the hospital. The objective was to minimize bias at the time of diagnostic inference. A guiding script was used as a tool with the patients' clinical histories, containing information pertinent to the process of diagnostic inference, then, from the identification of the signs and symptoms, the specialist should answer whether or not he agreed with each diagnosis presented. The discussions took place exhaustively by the participants until there was $100 \%$ agreement between them.

Shortly afterwards, a literature review was carried out in order to elaborate the CD and OD of the validated ND in the focal group according to the recommendations of the Preferred Reporting Items for Systematic Review sand Meta-Analyzes - PRISMA ${ }^{(9)}$ guideline. In order to guide the present review, the following guiding question was formulated: which $C D$ and $O D$ of the affirmations of validated ND in the focal group? Thus, articles were searched in the following databases/libraries: Medical Literature Analysis and Retrieval System Online (MEDLINE), via PubMed; Cochrane Library; The Cumulative Index to Nursing and Allied Health Literature (CINAHL) and the Latin American Literature in Health Sciences (LILACS). Therefore, scientific articles were searched through the following Descriptors in Health Sciences (DeCS) and Medical Subject Headings Terms (MeSH): Hospitalization; Signs and Symptoms; Epidemiological Factors; Acquired Immunodeficiency Syndrome.
The bibliographic survey was carried out by a single researcher from May to June 2017. The eligibility criteria used for the selection of the articles analyzed were: complete articles in Portuguese, English or Spanish, freely available. Thus, case or experience reports, letters, editorials and that did not address the proposed theme were excluded. A total of 807 articles were found which, after using the inclusion criteria, resulted in a sample of 18 articles.

The selected articles were submitted to a detailed reading for the extraction of data that included the identification of the characteristics of the periodicals and methodologies of the study. Subsequently, an information frame was constructed with the data of the articles: authors, title, periodical, country, year of publication, objective, design, population and results.

\section{Analysis of the results and statistics}

The ND analyzed in the focus group, by consensus were grouped according to the Basic Human Needs (BHN), in psychobiological, psychosocial, and psycho-spiritual categories. Next, the CD and OD were developed, representing the concept in the literature, and in the reality of the professional practice in the context of the nurse's actions with individuals with Aids. Then, a database was constructed using Microsoft Excel 2013 software, with the respective diagnoses, definitions, and clinical history of each patient.

Then, this material was sent to the selected experts, via electronic communication. The time agreed for return was 30 days. Once received from the experts, the material was compiled and processed by the SPSS software, version 20.0 for Windows, to calculate the Content Validity Index (CVI), due to the authors' greater ability to use it rather than Excel. The indexes were calculated for the scores attributed by the ICNP' ${ }^{\circ}$ center researchers for each CD/OD, based on a five-point Likert scale ( 1 = not relevant, $2=$ a little relevant, $3=$ relevant, $4=$ very relevant, $5=$ extremely relevant). Items one and two of the scale, as well as items three, four and five were grouped for the CVI calculation. Items that achieved a CVI $\geq 0.80$ were considered validated.

\section{RESULTS}

A total of 100 people with Aids, mean age $39 \pm 11$ years old, men (57.78\%), married (63.85\%), autonomous (41.33\%), and white (54.21\%) participated in the study. Thus, 35 ND were identified, of which only 18 were validated in the focus group, with an agreement percentage of $100 \%$, according to Charts 1 and 2 .

Chart 2 shows the ND classified in psychosocial and spiritual $\mathrm{NHBs}$, and validated in the focus group with a $100 \%$ of agreement.

The integrative literature review resulted in a total of 807 articles. After reading the title and abstract, 36 articles in MEDLINE, 30 articles in CINAHL and 37 in LILACS and four in the Cochrane Library, were selected for reading in their entirety, totaling 107.

In the sequence, articles in duplicate found in the databases $(n=44)$ and those lacking elements that would support the construction of the proposed definitions ( $n=45$ ) were excluded. After reading these in their entirety, 18 papers were selected which presented relevant content for the construction of the $C D$ and OD definitions of the ND.

In the countries where the studies were carried out, 8 of these occurred in South America (Brazil), 4 in North America (USA), 2 
Chart 1 - Distribution of Nursing Diagnoses for individuals with Aids, according to psychobiological Basic Human Needs, Brazil, 2017

\begin{tabular}{|l|l|}
\hline Psychobiological BHN & Nursing diagnoses \\
\hline Oxygenation & Dyspnea \\
\hline Nutrition & Impaired swallowing \\
\hline \multirow{2}{*}{ Elimination } & Urinary incontinence \\
\cline { 2 - 2 } & Bowel incontinence \\
\hline Sleep and Rest & Insomnia \\
\hline Body Care & Impaired hygiene of the scalp \\
\hline Neurological regulation & Impaired Consciousness \\
\hline Immune regulation & Risk for Infection \\
\hline Therapy & Impaired adherence to the therapeutic regimen \\
\hline
\end{tabular}

Chart 2 - Distribution of the Nursing Diagnoses for individuals with Aids, according to the psychosocial and spiritual Basic Human Needs, Brazil, 2017

\begin{tabular}{|l|l|}
\hline Psychosocial BHN & Nursing diagnoses \\
\hline Emotional safety & Fear about death \\
\hline Learning & Knowledge of deficient health \\
\hline \multirow{2}{*}{ Gregarious } & Loneliness \\
\cline { 2 - 3 } & Lack family support \\
\hline Acceptance & Impaired acceptance of health status \\
\hline Self-image & Marked body changes \\
\hline \multirow{2}{*}{ Psychosocial care } & Alcohol abuse \\
\cline { 2 - 3 } & Tobacco abuse \\
\hline Psycho-spiritual BHN & Nursing diagnoses \\
\hline Religious/ Spirituality & Impaired religious belief \\
\hline
\end{tabular}

were developed in Europe (Germany and Portugal), 2 in Asia (Japan, Nepal), one in Africa (Ethiopia) and a multicenter study has involved countries from several continents (Asia, Africa and the Americas). In terms of language, 8 studies were in Portuguese and 10 in English. The studies consisted of 5 transverse, 5 cohorts, 4 methodological studies, 2 literature reviews and 2 clinical trials. In addition, 15 occurred in hospitals and 3 in outpatient clinics.

The conceptual and operational definitions of the 18 ICNP $^{\circ}$ for people living with Aids were sent to the selected judges using the Delphi technique in two rounds. After the second round as all settings reached the $C V I \geq .80$, these were considered validated for content.

\section{DISCUSSION}

The literature describes several difficulties mentioned by professionals in the process of diagnosing. Among them are the lack of time, excess of activities, the excessive number of patients, lack of staff, awareness of the team, knowledge and experience with the use of the classification. A strategy to minimize this problem is content validation and clinical studies of nursing diagnoses, which intend, by means of several methods, to confer legitimacy to the diagnostic process in specific populations. As studies in this field progress, there is a refinement of classifications by identification of factors contributing to the occurrence of such an event, as well as signs and symptoms that best describe the responses of the individual, family or human collectivity to the health processes and disease ${ }^{(5)}$.

In this context, the conceptual and operational definitions are vital components in the research related to nursing diagnoses, as they establish a connection between observation and scientific investigation. The purpose of these definitions is to describe what will be measured and how the presence of a sign or symptom can be evaluated ${ }^{(4)}$. In addition, they may serve to increase the reliability and validity of clinical data related to diagnoses, facilitate replication of research, the improvement of the researcher's ability to correlate the findings of previous studies, and support the construction of interventions ${ }^{(6)}$.

Chart 3 - Conceptual and operational definitions of Nursing Diagnostics for people with Aids not included in Classification for Nursing Practice version 2017, Brazil, 2017

\begin{tabular}{|c|c|c|}
\hline Nursing Diagnosis & Conceptual definitions & Operational definitions \\
\hline Dyspnea & $\begin{array}{l}\text { Forced air movement into and out of the lungs, shortness } \\
\text { of breath, associated with circulating oxygen deficiency, } \\
\text { feeling of discomfort and anxiety }{ }^{(10)} \text {. } \\
(\mathrm{CVI}=1,0)\end{array}$ & $\begin{array}{l}\text { To evaluate the dyspnea by means of the identification of the } \\
\text { signs of fatigue, with the use of the accessory musculature. } \\
\text { Measure the degree of dyspnea using the Medical Research } \\
\text { Council scale(10). Measures ventilation and perfusion by means } \\
\text { of pulse oximeter and arterial blood gas. } \\
(\mathrm{CVI}=0,98)\end{array}$ \\
\hline $\begin{array}{l}\text { Impaired } \\
\text { swallowing }\end{array}$ & $\begin{array}{l}\text { Difficulty swallowing that arises from a variety of } \\
\text { disorders affecting the neural, motor, and/or sensory } \\
\text { systems underlying the swallowing function. There is } \\
\text { difficulty of oral control of the food bolus and greater } \\
\text { time of oral transit. Based on the presence of coughing } \\
\text { and/or gagging during feeding, regurgitation, low diet } \\
\text { acceptance and consequent weight loss }{ }^{(11)} \text {. } \\
(\mathrm{CVI}=0,92)\end{array}$ & $\begin{array}{l}\text { Measure the commitment of swallowing as well as categorize } \\
\text { it according to severity grades using the Gugging Swallowing } \\
\text { Screen (GUSS) scale }{ }^{(11)} \text {. } \\
(\mathrm{CVI}=0,91)\end{array}$ \\
\hline
\end{tabular}


Chart 3

\begin{tabular}{|c|c|c|}
\hline Nursing Diagnosis & Conceptual definitions & Operational definitions \\
\hline $\begin{array}{l}\text { Urinary } \\
\text { incontinence }\end{array}$ & $\begin{array}{l}\text { Involuntary loss of urine. Based on altered urinalysis for } \\
\text { density, piocytes, proteins and glucose }{ }^{(12)} \text {. } \\
(\mathrm{CVI}=0,98)\end{array}$ & $\begin{array}{l}\text { Identify increased urinary frequency, nocturia, urgency, increase } \\
\text { or reduction or absence of bladder sensitivity, hesitancy, short } \\
\text { urinary blast, intermittence, urge force, scattered urination, } \\
\text { and incomplete emptying sensation. Evaluate through the } \\
\text { International Consultation on Incontinence Questionnaire - } \\
\text { Short Form }(I C I Q-S F)^{(12)} \text {. } \\
(\mathrm{CVI}=0,94)\end{array}$ \\
\hline Bowel incontinence & $\begin{array}{l}\text { Complaint of loss of any amount of feces repeated times. } \\
\text { Based on changes in stool appearance and increased } \\
\text { bowel frequency }{ }^{(13)} \text {. } \\
(\mathrm{CVI}=1,0)\end{array}$ & $\begin{array}{l}\text { Measure the anal incontinence index by means of Fecal } \\
\text { incontinence quality of life scale (FIQL), which can be classified } \\
\text { as frequency, generating a score of } 0 \text { normal continence and } 20 \\
\text { complete incontinence }{ }^{(13)} \text {. } \\
(\mathrm{CVI}=0,97)\end{array}$ \\
\hline $\begin{array}{l}\text { Impaired hygiene of } \\
\text { the scalp }\end{array}$ & $\begin{array}{l}\text { Scalp cleansing status changed. Grounded by reduced } \\
\text { hygiene, scalp with dirt, showing oiliness, peeling, } \\
\text { infestations, unpleasant odor, pruritus, hair loss }{ }^{(14)} \text {. } \\
(\mathrm{CVI}=1,0)\end{array}$ & $\begin{array}{l}\text { Verify through the inspection the presence of dirt, dandruff, } \\
\text { and pediculosis; on palpation to investigate the presence of oily } \\
\text { capillary fiber }{ }^{(14)} \text {. } \\
(\mathrm{CVI}=0,96)\end{array}$ \\
\hline $\begin{array}{l}\text { Impaired } \\
\text { Consciousness }\end{array}$ & $\begin{array}{l}\text { Qualitative change in the overall pattern of mental } \\
\text { functioning which the individual feels to be radically } \\
\text { different from his usual mode of functioning. Grounded } \\
\text { by decreased awareness, difficulty staying alert, } \\
\text { disorientation, confusion and delusions }{ }^{(8)} \text {. } \\
(\mathrm{CVI}=0,89)\end{array}$ & $\begin{array}{l}\text { Identify alteration in the overall pattern of mental functioning } \\
\text { through neurological physical examination, application of } \\
\text { the Glasgow Coma Scale and Mini Mental State Examination } \\
(\mathrm{MMSE})^{(8)} \text {. } \\
(\mathrm{CVI}=0,87)\end{array}$ \\
\hline Insomnia & $\begin{array}{l}\text { Difficulty with initiation, duration, consolidation or quality } \\
\text { of sleep that occurs despite the adequate opportunity } \\
\text { for sleep, and which results in some form of daytime } \\
\text { involvement. Based on stress, difficulty in resting and use of } \\
\text { medications for sleep }{ }^{(15)} \text {. } \\
(\mathrm{CVI}=0,98)\end{array}$ & $\begin{array}{l}\text { To evaluate the quality of sleep of the patients through the } \\
\text { application of instrument called "Pittsburgh Sleep Quality Index } \\
\text { (PSQI)"(15). } \\
\text { (CVI }=0,97)\end{array}$ \\
\hline Risk for Infection & $\begin{array}{l}\text { It is the probability of a pathological process occurring by } \\
\text { invasion of the body by pathogenic microorganisms, or } \\
\text { invasion of the environment or environment where the } \\
\text { infectious agent circulates. Characterized by the insufficient } \\
\text { adoption of preventive measures, which can be determined } \\
\text { by the reduction of the immunological capacity of the } \\
\text { individual, or by the environment to which he is exposed }{ }^{(16)} \text {. } \\
(\mathrm{CVI}=0,96)\end{array}$ & $\begin{array}{l}\text { Evaluate the devices used in the patient (whether } \\
\text { hematogenous, urinary or respiratory), as well as the length } \\
\text { of stay, functionality, cleanliness and purpose. Analyze the } \\
\text { leukogram, vital signs, as well as antibiogram }{ }^{(16)} \text {. } \\
(\mathrm{CVI}=0,95)\end{array}$ \\
\hline $\begin{array}{l}\text { Impaired adherence } \\
\text { to the therapeutic } \\
\text { regimen }\end{array}$ & $\begin{array}{l}\text { Degree of disagreement between a person's behavior and } \\
\text { the directions received from the health care professional } \\
\text { as the patient attempts to maintain his or her personal } \\
\text { identification. Based on difficulty in following the indicated } \\
\text { therapy and lack of significant improvement }{ }^{(17)} \text {. } \\
(\mathrm{CVI}=0,94)\end{array}$ & $\begin{array}{l}\text { To assess the degree of adherence through the Assessment of } \\
\text { Adherence to Antiretroviral Therapy Questionnaire (CEAT-VIH) })^{(17)} \text {. } \\
(\mathrm{CVI}=0,89)\end{array}$ \\
\hline Fear about death & $\begin{array}{l}\text { Fear of disease progression and death, based on behavioral } \\
\text { changes: anxiety, anguish, introspection, reports of fear of } \\
\text { the death process and death, and may be accompanied by } \\
\text { isolation }{ }^{(18)} \text {. } \\
(\mathrm{CVI}=0,89)\end{array}$ & $\begin{array}{l}\text { To evaluate the fear of death through the application of the } \\
\text { Collett-Lester Death Fear Scale }(E M M C L)^{(18)} \text {, which consists of } 28 \\
\text { items, and contains four subscales with seven items each. } \\
(\mathrm{CVI}=0,88)\end{array}$ \\
\hline $\begin{array}{l}\text { Knowledge of } \\
\text { deficient health }\end{array}$ & $\begin{array}{l}\text { Inadequate follow-up of instructions and verbalization of } \\
\text { the problem. Grounded by difficulty in understanding and } \\
\text { performing health information }{ }^{(19)} \text {. } \\
(\mathrm{CVI}=0,89)\end{array}$ & $\begin{array}{l}\text { To identify the level of health knowledge regarding HIV/AIDS, } \\
\text { through the application of the HIV/AIDS Attitudes Scale }{ }^{(19)} \text {, } \\
\text { which is composed of religiosity and magical practices, } \\
\text { technical and scientific information, illicit drug use, sexuality } \\
\text { and prejudice. } \\
(\mathrm{CVI}=0,86)\end{array}$ \\
\hline Loneliness & $\begin{array}{l}\text { Cognitive perception that the social relationships existing } \\
\text { in one's life are insufficient or inadequate, generating an } \\
\text { affective reaction of sadness. Grounded by isolation and } \\
\text { feeling of emptiness }{ }^{(20)} \text {. } \\
(\mathrm{CVI}=0,92)\end{array}$ & $\begin{array}{l}\text { Identify the presence of the feeling of loneliness through the } \\
\text { UCLA Solitude Scale }{ }^{(20)} \text {. } \\
(\mathrm{CVI}=0,90)\end{array}$ \\
\hline Lack family support & $\begin{array}{l}\text { Impaired ability to adapt the family to new family events. } \\
\text { Based on the offer of reduced family support that may } \\
\text { interfere with the treatment }{ }^{(21)} \text {. } \\
(\mathrm{CVI}=0,88)\end{array}$ & $\begin{array}{l}\text { Identify low family support through the presence of the } \\
\text { following characteristics: verbal expressions of lack of family } \\
\text { support, easy crying, isolation, and reports of family neglect }{ }^{(21)} \text {. } \\
(\mathrm{CVI}=0,85)\end{array}$ \\
\hline
\end{tabular}


Validation of the definitions of nursing diagnoses for individuals with Aids Souza Neto VL, Costa RTS, Santos WN, Fernandes SF, Lima DM, Silva RAR.

Chart 3 (concluded)

\begin{tabular}{|c|c|c|}
\hline Nursing Diagnosis & Conceptual definitions & Operational definitions \\
\hline $\begin{array}{l}\text { Impaired } \\
\text { acceptance of } \\
\text { health status }\end{array}$ & $\begin{array}{l}\text { Difficulty of acceptance of the diagnosis. Based on feelings } \\
\text { and behaviors such as: sadness lack of self-confidence, } \\
\text { behavioral changes and reduction of future prospects }{ }^{(19)} \text {. } \\
(\mathrm{CVI}=0,89)\end{array}$ & $\begin{array}{l}\text { Identify the low acceptance of the state of health through } \\
\text { affective blunting, irritability, aggressiveness, high tone of voice, } \\
\text { negativity for any therapeutic action }{ }^{(19)} \text {. } \\
(\mathrm{CVI}=0,86)\end{array}$ \\
\hline $\begin{array}{l}\text { Marked body } \\
\text { changes }\end{array}$ & $\begin{array}{l}\text { Change in body fat distribution. Based on lipoatrophy or } \\
\text { lipohypertrophy, weight loss }{ }^{(22)} \text {. } \\
(\mathrm{CVI}=0,98)\end{array}$ & $\begin{array}{l}\text { Evaluate the presence of marked corporal modifications } \\
\text { through the Subjective Global Assessment (AGS) instrument. } \\
\text { Investigate issues inherent in the patient's ingestion of food; fat } \\
\text { accumulation; changes in weight; changes in the tissues around } \\
\text { the face, arms, hands, shoulders and legs }{ }^{(22)} \text {. } \\
(\mathrm{CVI}=0,97)\end{array}$ \\
\hline Alcohol abuse & $\begin{array}{l}\text { Excessive consumption of alcohol linked to frequent } \\
\text { adverse consequences. Fulfills criteria for dependency. } \\
\text { Based on behavioral changes and reports of use by the } \\
\text { patient and/or family members } \\
(\mathrm{CVI}) \\
(\mathrm{CV}=0,99)\end{array}$ & $\begin{array}{l}\text { To assess alcohol abuse through the HIV/AIDS Attitudes } \\
\text { Scale, which is composed of religiosity and magical practices, } \\
\text { technical and scientific information, illicit drug use, sexuality } \\
\text { and prejudice } \\
(\mathrm{CVI}=0,97)\end{array}$ \\
\hline Tobacco abuse & $\begin{array}{l}\text { Excessive smoking /tobacco consumption linked to } \\
\text { frequent adverse effects. Fulfills criteria for dependency }{ }^{(24)} \text {. } \\
(\mathrm{CVI}=0,91)\end{array}$ & $\begin{array}{l}\text { Assessing tobacco abuse by means of a Scale of attitudes } \\
\text { toward HIV/AIDS, which is composed of religiosity and magical } \\
\text { practices, technical and scientific information, legal drug use, } \\
\text { sexuality and prejudice }{ }^{(19,24)} \text {. } \\
(\mathrm{CVI}=0,92)\end{array}$ \\
\hline $\begin{array}{l}\text { Impaired religious } \\
\text { belief }\end{array}$ & $\begin{array}{l}\text { Decline in spirituality. Grounded by spiritual anguish, } \\
\text { anger of a greater being and feeling guilty }{ }^{(25)} \text {. } \\
(\mathrm{CVI}=0,89)\end{array}$ & $\begin{array}{l}\text { Identify the presence of impaired religious belief through the } \\
\text { application of the Spiritual Well-being Scale (SBS) })^{(25)} \text {. } \\
(\mathrm{CVI}=0,87)\end{array}$ \\
\hline
\end{tabular}

Note: CVI - Content Validity Index

Thus, this whole process favors nurses' decision making, accuracy in the choice of ND, which reflects the real situation of the care patients, as well as improvement in communication among the members of the team through the nursing record.

As an initial step of the validation studies, we have the integrative literature review that is the method used to construct the definitions of the elements that make up an ND. The definitions serve as instruments for conducting the practice, since they describe the abstract or theoretical meaning of the concepts studied (conceptual definition) and specify the operations that researchers must do to collect information, indicating how the concept is found or measured in practice (operational definition), congruent with the conceptual definition ${ }^{(4)}$.

The importance of this construction relates to the processes involved for clinical reasoning based on the data obtained in the evaluation. Thus, the conceptual and operational definitions clarified the understanding for the process of clinical reasoning for diagnostic inference. With the development of this skill, the diagnostic reference standard established in the conduction of validation research in nursing is improved, as well as avoidance of generalization of the judgment of diagnostic inferences in clinical practice.

For the present study, the results from the conceptual and operational definitions allowed the mobilization of cognitive processes to analyze the basic human needs of people living with Aids.

In this sense, the clinical evidence produced by studies in the area, in fact, guides the practice of caring, which confers legitimacy to actions. The accuracy in identifying the signs and symptoms that contribute to the occurrence of the phenomena is indisputable for a diagnostic reasoning with higher predictive value. It is necessary to approach nurses with studies that name, define and validate the components of ND, to improve the quality of care and to directly influence the reestablishment of the health conditions of patients attended ${ }^{(6)}$.

The construction of the definitions of the elements that make up the diagnostic concept, through the integrative review, can best describe what is in practice; besides, it can favor the planning of the offered nursing care, minimizing the complications and the suffering of the patients.

Authors reinforce that the construction and validation of conceptual and operational definitions is a strategy in the search for standardization of the language used by nurses, since they facilitate refinement and improvement of classifications, which favors critical thinking and reinforce decision making by the nurse. In addition, it aims to facilitate communication among team members, improve diagnostic accuracy and care planning, and contribute to research in the area, favoring the teaching of the nursing discipline ${ }^{(4-5)}$. The relevance of the deepening in the knowledge about the phenomena presented by the patients is highlighted. The description of the elements that make up such phenomena assists in this deepening and, consequently, legitimizes nursing care.

Thus, it is essential to study the conceptual and operational definitions of ND in relation to its revision and evaluation in different populations for the scientific identification of accuracy, in order to contemplate as many indicators and possible terms as possible, facilitating their nurses in diverse populations. Thus, ND are now based on evidence, capable of being generalized and capable of being used by these professionals.

In addition, a study of validation of conceptual and operational definitions of ND, which can improve already existing taxonomies, becomes relevant, since it can give the necessary strength to the practice of Nursing, contributing to the visibility of the profession. In addition, a study points to knowledge gaps about ND in people living with Aids, which makes this research even more important ${ }^{(2)}$. 
Thus, the construction of the definitions facilitates the understanding of ND by the interdisciplinary team, making possible the most efficient and uniform patient care. They make the understanding of this phenomenon easier and such definitions can be used as a teaching strategy, as well as facilitating the nursing record and data analysis of people living with Aids.

In individuals with Aids, the dyspnea ND results from the compromise of the pulmonary function caused by the virus (which can damage the lymphocytes and alveolar macrophages), opportunistic infections, lung neoplasms and the use of antiretroviral, such as tenofovir, which leads to mitochondrial toxicity with different degrees of myopathy. This, in turn, depresses the respiratory activity, as it interferes with the integrity of respiratory muscles ${ }^{(26)}$.

This clientele is potentially a population at greater risk of developing opportunistic infections, which contributes to a significant increase in hospitalization period and mortality rate. In this sense, the risk of infection is related to immunosuppression, inadequate secondary defenses, lymphopenia and insufficient knowledge ${ }^{(16)}$.

On the other hand, the excess intestinal ND may be associated with the presence of parasitoses. These have a higher risk of presenting a parasitic infection, in addition, they present more intense symptomatology in order to contribute to complication of the clinical picture. The excessive increase of the intestinal frequency caused by parasitoses is very frequent in this group that leads to malabsorption of nutrients, leading to cachexia ${ }^{(13)}$.

Over time, a marked body modification, related to lipoatrophy, lipohypertrophy or weight loss, may be present in this group. Such alteration occurs as a consequence of the Lipodystrophy Syndrome that is observed in the therapeutic regimens that contemplate the antiretrovirals of the classes of nucleoside analog reverse transcriptase inhibitors and protease inhibitors. These can lead to loss of peripheral subcutaneous tissue and increased central fat ${ }^{(22)}$.

The immunosuppression, present in individuals with Aids, can cause manifestations in the oropharynx, from opportunistic diseases, which produce lingual pain when swallowing, burning and involvement of the pharynx. These factors lead to impaired swallowing, which was identified in the present study, and was portrayed by the presence of coughing and/or gagging during eating, regurgitation, low dietary acceptance, and consequent weight loss ${ }^{(27)}$.

The ND, impaired spontaneous urinary elimination in individuals with Aids, can be associated with Urinary Tract Infections (UTI), and caused by pathogenic microorganisms present in the urinary system. Because of immunosuppression, bacteria spread to the bladder, bind to the epithelium, and begin to colonize it, aiming to escape from the defense mechanisms of the human body and generate the infection. Among the symptoms associated with UTI, involuntary loss of urine, or compromised spontaneous bladder elimination, are common ${ }^{(28)}$.

Another ND associated with individuals with Aids was insomnia. One study showed that sleep quality is significantly reduced in this group when compared to the population that does not have the virus. Poor sleep quality and increased distress has been associated with reduced TCD4 cell counts. In addition, sleep quality is affected by anxiety, reduced general well-being, and depression ${ }^{(29)}$.

The altered state of consciousness, on the other hand, results from a qualitative change in the global pattern of mental functioning radically different from its usual mode of functioning, affecting its quality of life, characterized by decreased awareness, difficulty staying alert, disorientation, confusion and delusion s $^{(16)}$.

With regard to the impaired hygiene pattern of the damaged scalp, it may be related to a self-care deficit that causes inadequate hygiene habits. In addition, seborrheic dermatitis affects a large proportion of people living with Aids, with a prevalence of 20$83 \%$, manifesting through erythematous-scaly plaques that affect the scalp, impairing hygiene standards ${ }^{(14)}$.

Knowledge about poor health status may be related to inadequate follow-up of instructions and verbalization of the problem. In addition, the difficulty of understanding and executing health information may be associated with lack of knowledge about the disease and treatment, directly affecting adherence to therapy ${ }^{(19)}$.

Adherence to the impaired therapeutic regimen is associated with worsening of the clinical condition. Such poor adherence may associate the complexity involved in the treatments, the long duration, the various side effects, low educational level, consumption of alcoholic beverages and other drug $\mathrm{s}^{(23-24)}$. However, adherence to drug therapy is essential for the suppression of viral replication, avoiding opportunistic infections ${ }^{(17)}$.

In addition, alcohol and tobacco abuse may interfere with treatment adherence, causing a worse prognosis, increasing morbidity and mortality, reducing the quality of life, thus causing a decline in CD4 + Tlymphocytes, and increasing viral load. The study demonstrated that these substances were used as a way of escape in the face of the adversities imposed by the disease ${ }^{(23)}$.

The low family support was evident in the clientele. The study indicates that this low support generates negative repercussions that directly impact the process of living with the disease and the low acceptance of the health condition. The research also found that family support is one of the most effective forms of social support, which is an important protective factor for the development of depressive symptoms ${ }^{(21)}$.

After the diagnosis of Aids is common the appearance of feeling of loneliness and fear of dying. The first one stems from the fear of telling and being stigmatized by friends, family members and other social groups. Often, due to fear of stigma and prejudice, they decide not to reveal the diagnosis, in the face of this situation social isolation develops, leading to depressive symptoms, which affects a large part of the clientele. While Fear of Dying is related to the diagnosis of an incurable disease, associated with a fear of the unknown, the progression of the disease and death that is now seen as imminent ${ }^{(19)}$.

Faced with these feelings, religious belief emerges as a coping strategy, and becomes a source of strength and hope for strength when confronting the adversities related to the diseas $\mathrm{e}^{(30)}$. However, in the present study, impaired religious belief was a ND present in individuals with Aids.

Finally, we mean the importance of describing such definitions so that nurses can be assisted in proposing ND that represent, in fact, the response presented by people living with Aids, since it clarifies terms with standardized definitions. In addition, knowledge about conceptual and operational definitions can support the teaching of the nursing discipline and future studies with a studied phenomenon, which may contribute to avoid misunderstandings in the evaluation of patients. 


\section{Limitations of the study}

The content validation process was considered one limitation of this study. This is a subjective activity that requires skill and abilities of inductive and deductive type, by the selected experts. Moreover, studies that could bring some contribution may have been excluded in the integrative review stage, when the researchers read only titles and abstracts, since only well-structured abstracts that met the criteria of were selected. Another limitation is that articles written in languages other than Portuguese, Spanish and English were not included.

\section{Contributions to the nursing area, health, or public policy}

The study will contribute to the advances and incorporation of a universal language in the description of professional practice, improving the quality of nursing care in the national scenario, respecting the integrity of the human being, and contributing to the strengthening of nursing as science.

\section{CONCLUSIONS}

The study identified 35 ND of ICNP ${ }^{\circ}$ for individuals with Aids, but only 18 were validated. Thus, the conceptual and operational definitions of these statements were developed, which were all validated with a $C V I \geq 0.8$. The nursing diagnoses presented, as well as their validated conceptual and operational definitions, represent human conditions and responses to current or potential health problems and life processes of individuals with Aids, which are interconnected to the need of care of this population.

The validated CD and OD in this study will enable nurses to analyze clinical inferences and compare with such definitions and thus reaffirm ND, which may determine clarity and assertiveness in nursing interventions. These definitions establish a link between observation and scientific research, favoring nurses' ability to recognize and identify signs and symptoms that are specific diagnoses to people living with Aids.

It is hoped to continue this research in order to carry out the clinical validation of the definitions researched in this study. Finally, the validated definitions in this study can contribute to a systematic approach to nursing care in clinical practice, giving greater clarity and ease of implementation.

\section{FUNDING/ACKNOWLEDGMENT}

Research funded by the National Council of Science and Technology (CNPq), through the Universal Call 01/2016 - Track A, process no 402978 / 2016-1 - “Diagnoses/results and nursing interventions of ICNP ${ }^{\circ}$ for people living with Aids: structuring of a terminological subset".

\section{REFERENCES}

1. Souza Neto VL, Silva RAR, Silva CC, Negreiros RV, Rocha CCT, Nóbrega MML. Proposal of nursing care plan in people hospitalized with AIDS. Rev Esc Enferm USP [Internet]. 2017 [cited 2018 Oct 07];51:e03204. Available from: http://www.scielo.br/pdf/reeusp/v51/1980-220X-reeusp51-e03204.pdf

2. Costa RHS, Nelson ARC, Prado NCC, Rodrigues EHF, Silva RAR. Nursing diagnoses and their components in acquired immune deficiency syndrome patients. Acta Paul Enferm [Internet]. 2016[cited 2018 Oct 20];29(2):146-53. Available from: http://www.scielo.br/pdf/ape/v29n2/ en_1982-0194-ape-29-02-0146.pdf

3. Garcia TR. Classificação Internacional para Prática da Enfermagem - CIPE ${ }^{\oplus}$ : aplicação à realidade brasileira. Porto Alegre: Artmed; 2018.

4. Carneiro CS, Lopes CT, Lopes JL, Santos VB, Bachion MM, Barros AL. Conceptual and Operational Definitions of the Defining Characteristics and Related Factors of the Diagnosis Ineffective Health Management in People with Heart Failure. Int J Nurs Knowl[Internet]. 2017[cited 2018 Nov 23];28(2):76-87. Available from: https://www.ncbi.nlm.nih.gov/pubmed/26549691

5. Correia MDL, Duran ECM. Conceptual and operational definitions of the components of the nursing diagnosis Acute Pain (00132). Rev LatinoAm Enfermagem [Internet]. 2017 [cited 2018 Feb 21];25:e2973. Available from: http://www.scielo.br/pdf/rlae/v25/0104-1169-rlae-25-e2973.pdf

6. Goncalves MCS, Brandao MAG, Duran ECM. Validation of the defining characteristics of the nursing diagnosis impaired comfort in oncology. Acta Paul Enferm [Internet]. 2016[cited 2018 Mar 24];29(1);115-24. Available from: http://www.scielo.br/pdf/ape/v29n1/en_1982-0194ape-29-01-0115.pdf

7. Melo DM, Barbosa AJG. [Use of the Mini-Mental State Examination in research on the elderly in Brazil: a systematic review] Ciênc Saúde Coletiva [Internet]. 2015 [cited 2017 Nov 28];20(12):3865-76. Available from: http://www.scielo.br/pdf/csc/v20n12/1413-8123csc-20-12-3865.pdf. Portuguese

8. Debone MC, Pedruncci ESN, Candido MCP, Marques S, Kusumota L. Nursing diagnosis in older adults with chronic kidney disease on hemodialysis. Rev Bras Enferm [Internet]. 2017 [cited 2018 Nov 23]; 70(4):800-5. Available from :http://www.scielo.br/pdf/reben/ v70n4/0034-7167-reben-70-04-0800.pdf

9. Main items to report Systematic reviews and Meta-analyzes: The PRISMA recommendation. Epidemiol Serv Saúde [Internet]. 2015 [cited 2018 Nov 23];24(2):335-42. Available from: http://www.scielo.br/pdf/ress/v24n2/2237-9622-ress-24-02-00335.pdf

10. Tsiligianni IG, Alma HJ, Jong C, Jelusic D, Wittmann M, Schuler M, et al. Investigating sensitivity, specificity, and area under the curve of the Clinical COPD Questionnaire, COPD Assessment Test, and Modified Medical Research Council scale according to GOLD using St George's Respiratory Questionnaire cutoff 25 (and 20) as reference. Int J Chron Obstruct Pulmon Dis [Internet]. 2016 [cited 2018 Aug 08];18;11:104552. Available from: https://www.ncbi.nlm.nih.gov/pubmed/27274226 
11. Lopes M, Freitas E, Oliveira M, Dantas E, Azevedo N, Rodrigues P, et al. Impact of the systematic use of the Gagging Swallowing Screen in patients with acute ischaemic stroke. Eur J Neurol[Internet]. 2019 [cited 2018 Aug 08]; May;26(5):722-726.Available from: https://www.ncbi. nlm.nih.gov/pubmed/30298612

12. Hikita K, Honda M, Kawamoto B, Tsounapi P, Muraoka K, Sejima T, et al. Evaluation of Incontinence after Robot-Assisted Laparoscopic Radical Prostatectomy: Using the International Consultation on Incontinence Modular Questionnaire Short Form and Noting the Number of Safety Pads Needed by Japanese Patients. YonagoActa Med [Internet]. 2017 [cited 2018 Aug 08]; 60(1):52-5. Available from: https://www.ncbi.nlm. nih.gov/pubmed/28331422

13. Hsu LF, Hung CL, Kuo LJ, Tsai PS. An abbreviated Faecal Incontinence Quality of Life Scale for Chinese-speaking population with colorectal cancer after surgery: cultural adaptation and item reduction. Eur J Cancer Care (Engl) [Internet]. 2017 [cited 2018 Nov 24];26(5). Available from: https://www.ncbi.nlm.nih.gov/pubmed/27467830

14. Cunha GH, Araujo TL, Araujo FET, Cavalcante TF, Galvão MTG. Hygiene practices for patients with HIV/AIDS. Rev Gaúcha Enferm [Internet].2014 [cited 2017 Nov 26];35(3):137-44. Available from: http://www.scielo.br/pdf/rgenf/v35n3/1983-1447-rgenf-35-03-00137.pdf

15. Morris JL, Rohay J, Chasens ER. Sex Differences in the Psychometric Properties of the Pittsburgh Sleep Quality Index. J Womens Health (Larchmt) [Internet]. 2018 [cited 2019 Apr 20];27(3):278-82. Available from: https://www.ncbi.nlm.nih.gov/pubmed/29154713

16. Rudd KE, Seymour CW, Aluisio AR, Augustin ME, Bagenda DS, Beane A, et al. Association of the Quick Sequential (Sepsis-Related) Organ Failure Assessment (qSOFA) Score With Excess Hospital Mortality in Adults With Suspected Infection in Low and Middle-Income Countries. JAMA[Internet]. 2018 [cited 2017 Nov 26];319(21):2202-11. Available from: https://www.ncbi.nlm.nih.gov/pubmed/29800114

17. Abreu RM, da Silva Ferreira C, Ferreira AS, Remor E, Nasser PD, Carrilho FJ, et al. Assessment of Adherence to Prescribed Therapy in Patients with Chronic Hepatitis B. Infect Dis Ther[Internet]. 2016 [cited 2019 Apr 18];5(1):53-64. Available from: https://www.ncbi.nlm.nih.gov/ pubmed/26757720

18. Bužgová R, Janíková E. Adaption of the Collett-Lester Fear of Death Scale in a Sample of Nursing Students. Omega (Westport)[Internet]. 2017 [cited 2019 Apr 18];1:30222817725183.Available from:https://www.ncbi.nlm.nih.gov/pubmed/28792353

19. Feleke BE, Wasie B. Challenges of PMTCT Service Utilization in Amhara Region: A Comparative Cross-sectional Study. Ethiop J Health Sci [Internet]. 2018 [cited 2018 Aug 08];28(6):779-86. Available from: https://www.ncbi.nlm.nih.gov/pubmed/30607095

20. Barroso SM, Andrade VS, Midgett AH, Carvalho RGN. [Evidence of validity of Brazilian UCLA Loneliness Scale]. J Bras Psiquiatr [Internet]. 2016 [cited 2018 Aug 08];65(1):68-75. Available from: http://www.scielo.br/pdf/jbpsiq/v65n1/0047-2085-jbpsiq-65-1-0068.pdf Portuguese

21. Amiya RM, Poudel KC, Poudel-Tandukar K, Pandey BD, Jimba M. Perceived family support, depression, and suicidal ideation among people living with HIV/AIDS: a cross-sectional study in the Kathmandu Valley, Nepal. PLOS One [Internet]. 2014 [cited 2017 Nov 26];9(3):1-8. Available from: http://journals.plos.org/plosone/article?id=10.1371/journal.pone.0090959

22. Sacilotto LB, Pereira PCM, Manechini JPV, Papini SJ. Body Composition and Metabolic Syndrome Components on Lipodystrophy Different Subtypes Associated with HIV. J Nutr Metab [Internet]. 2017 [cited 2017 Nov 25];1(2):1-8. Available from: https://www.hindawi.com/ journals/jnme/2017/8260867/DOl:https://doi.org/10.1155/2017/8260867

23. Silva RAR, Costa RHS, Braz LCSB, Lucena IA, Ferreira KS, Duarte FHS. People living with AIDS: Association between nursing diagnoses and sociodemographic/clinical characteristics. Rev Bras Enferm [Internet].2018[cited 2019 Oct 07];71(5):2535-42. Available from: http://www. scielo.br/pdf/reben/v71n5/0034-7167-reben-71-05-2535.pdf

24. Souza Neto VL, Silva RAR, Rocha CCT, Costa RTS, Nóbrega MML. ICNP ${ }^{\circledR}$ nursing diagnoses for people with acquired immunodeficiency syndrome. Acta Paul Enferm [Internet]. 2017[cited 2018 Oct 07]; 30(6):573-81. Available from: http://www.scielo.br/pdf/ape/v30n6/ en_0103-2100-ape-30-06-0573.pdf

25. Sharif Nia H, Pahlevan Sharif S, Boyle C, Yaghoobzadeh A, Tahmasbi B, Rassool GH, et al. The Factor Structure of the Spiritual Well-Being Scale in Veterans Experienced Chemical Weapon Exposure. J Relig Health[Internet]. 2018 [cited 2019 Jan 12]; 57(2):596-608. Available from: https://www.ncbi.nlm.nih.gov/pubmed/28748326

26. Vanni S, Bianchi S, Bigiarini S, Casula C, Brogi M, Orsi S, et al. Management of patients presenting with haemoptysis to a Tertiary Care Italian Emergency Department: the Florence Haemoptysis Score (FLHASC). Intern Emerg Med [Internet]. 2017 [cited 2017 Nov 25];1 (2):1-8. Available from: https://www.ncbi.nlm.nih.gov/pubmed/28160237

27. Ottria L, Lauritano D, Oberti L, Candotto V, Cura F, Tagliabue A, et al. Prevalence of HIV-related oral manifestations and their association with HAART and CD4+ T cell count: a review. J Biol Regul Homeost Agents [Internet]. 2018 [cited 2017 Nov 25];32(2 Suppl. 1):51-59. Available from: https://www.ncbi.nlm.nih.gov/pubmed/29460518

28. Zizzi PT, Trevisan KF, Leister N, Cruz CS, Riesco MLG. Women's pelvic floor muscle strength and urinary and anal incontinence after childbirth: a cross-sectional study. Rev Esc Enferm USP [Internet]. 2017 [cited 2017 Nov 25]; 51:e03214. Available from: http://www.scielo.br/pdf/ reeusp/v51/1980-220X-reeusp-51-e03214.pdf

29. Silva RAR, Costa RHS, Nelson ARC, Duarte FHS, Prado NCC, Rodrigues EHF. Predictive factors for the Nursing Diagnoses in people living with Acquired Immune Deficiency Syndrome. Rev Latino-Am Enfermagem [Internet].2016 [cited 2018 Oct 07];24:e2712. Available from: http:// www.scielo.br/pdf/rlae/v24/0104-1169-rlae-24-02712.pdf

30. Silva RTS, Silva RAR, Rodrigues IDCV, Souza Neto VL, Silva BCO, Souza FMLC. Coping strategies of people living with AIDS in face of the disease. Rev Latino-Am Enfermagem [Internet]. 2018 [cited 2019 Oct 07];26:e2985. Available from: http://www.scielo.br/pdf/rlae/ v26/0104-1169-rlae-26-e2985.pdf 